\title{
Potensi Gulma Siam (Chromolaena odorata L.) sebagai Bahan Kompos untuk Pengembangan Bawang Merah Organik
}

\author{
Potential of Siam Weed (Chromolaena odorata L.) \\ as Compost Material for Organic Shallot Cultivation
}

\author{
Bambang Nugroho $^{1 *}$, Warmanti Mildaryani ${ }^{1}$,dan Sri Hartati Candra Dewi ${ }^{2}$ \\ ${ }^{1}$ Program Studi Agroteknologi, Fakultas Agroindustri, Universitas Mercu Buana Yogyakarta \\ Jl. Wates km 10 Argomulyo, Yogyakarta 55753, Indonesia \\ ${ }^{2}$ Program Studi Peternakan, Fakultas Agroindustri, Universitas Mercu Buana Yogyakarta \\ Jl. Wates km 10 Argomulyo, Yogyakarta 55753, Indonesia
}

Diterima 1 Oktober 2018/Disetujui 29 Juli 2019

\begin{abstract}
Siam weed growing in any locations can be used for developing organic agriculture in Indonesia. The research was to find the quantitative and qualitative potential of siam weed as compost material for organic shallot cultivation. This study was descriptive-quantitative research using survey method done in four regencies in Yogyakarta Special Province and laboratory analysis. Purposive random sampling was used in survey method to determine the samples by applying random sampling and nested design. Laboratory analysis was to know nutrient content of siam weed. Shallot was planted using siam weed compost

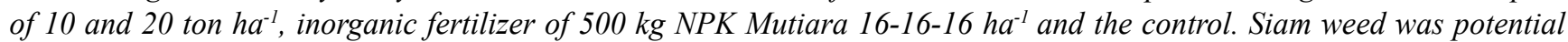
for developing organic shallot in Indonesia. Siam weed produced fresh biomass of 80 ton hat with the population density of 24-37 individual $\mathrm{m}^{-2}$ and spread over almost all locations in Yogyakarta Special Province. Siam weed also contained higher nutrients of $2.56 \% \mathrm{~N}, 0.38 \% \mathrm{P}$, and $2.41 \% \mathrm{~K}$ with $\mathrm{C} / \mathrm{N}$ ratio of 19.52 under the critical point of 30 so that easy to mineralized. The use of siam weed compost stimulated leaf number on shallot at 7 weeks after planting compared to the use of inorganic fertilizer and the control, but gave no significant yield of 19.71, 15.56, and 18.92 ton ha ${ }^{-1}$ of bulb, respectively.
\end{abstract}

Keywords: organic fertilizer, development, nutrient

\section{ABSTRAK}

Gulma siam yang tumbuh di berbagai tempat dapat dimanfaatkan untuk pengembangan pertanian organik di Indonesia. Penelitian ini bertujuan untuk mengetahui potensi kuantitatif dan kualitatif gulma siam sebagai bahan pembuatan kompos untuk pengembangan bawang merah organik. Penelitian ini merupakan penelitian deskriptif kuantitatif dengan metode survei yang dilakukan di empat kabupaten di Daerah Istimewa Yogyakarta dan analisis laboratorium. Penentuan sampel pada metode survei menggunakan metode purposive random sampling secara bertingkat dengan metode rancangan tersarang. Analisis laboratorium digunakan untuk mengetahui kandungan nutrisi gulma siam. Penanaman bawang merah dilakukan menggunakan kompos gulma siam dosis 10 dan 20 ton ha-1, pupuk inorganik NPK Mutiara 16-16-16 dosis $500 \mathrm{~kg} \mathrm{ha}^{-1}$, dan kontrol. Kompos gulma siam sangat potensial untuk pengembangan bawang merah organik di Indonesia. Produksi biomas gulma siam sangat tinggi mencapai 80 ton biomas segar ha $a^{-1}$ pada kerapatan 24-37 individu $m^{-2}$ dan tersebar di hampir seluruh lokasi di wilayah Daerah Istimewa Yogyakarta. Gulma siam juga mengandung unsur hara yang tinggi yaitu $2.56 \%$ $N, 0.38 \% \mathrm{P}$, dan $2.41 \% \mathrm{~K}$ dengan rasio $\mathrm{C} / \mathrm{N} 19.52$ di bawah titik kritis 30 sehingga mudah dan cepat termineralisasi. Penggunaan kompos gulma siam memberikan jumlah daun yang lebih tinggi pada 7 minggu setelah tanam dibandingkan dengan penggunaan pupuk inorganik dan kontrol, tetapi memberikan bobot umbi ha-1 yang tidak berbeda nyata yaitu masingmasing 19.71, 15.56, and 18.92 ton $\mathrm{ha}^{-1}$.

Kata kunci: pupuk organik, pengembangan, unsur hara

\footnotetext{
*Penulis untuk korespondensi. e-mail: b_nugr@yahoo.com
} 


\section{PENDAHULUAN}

Bawang merah merupakan komoditas sayuran yang mempunyai prospek pengembangan yang sangat baik karena disamping mempunyai nilai ekonomi yang tinggi, bawang merah semakin dibutuhkan masyarakat. Konsumsi bawang merah nasional pada tahun 2016 sebesar 698.178 ton dan diproyeksikan menjadi 755.687 ton pada tahun 2020 dengan rata-rata pertumbuhan $2,03 \%$ per tahun (Siagian, 2016). Sementara itu produksi bawang merah Indonesia terpusat di pulau Jawa dengan kontribusi sebesar $76.41 \%$ dari total produksi bawang merah Indonesia dengan produktivitas 9 ton $\mathrm{ha}^{-1}$ yang masih rendah bila dibandingkan dengan potensi produksinya yang mencapai 20 ton ha ${ }^{-1}$ (Pranata dan Umam, 2015). Rasio B/C usaha tani bawang merah juga masih rendah sebesar 0.6 dengan biaya produksi terbesar adalah benih (41\%), tenaga kerja (37\%), pupuk dan pestisida (17\%) (Simatupang et al., 2017). Selama ini produksi bawang merah dilakukan dengan sistem pertanian konvensional sehingga biaya produksi yang berasal dari faktor produksi pupuk dan pestisida menjadi tinggi dan menyebabkan rendahnya pendapatan petani. Oleh karena itu budidaya bawang merah secara organik menjadi solusi yang prospektif.

Indonesia mempunyai peluang yang tinggi untuk mengembangkan pertanian organik dengan potensi yang ada untuk dapat meningkatkan produksi pangan yang aman dikonsumsi (food safety attributes), kandungan nutrisi tinggi (nutritional attributes) dan ramah lingkungan (ecolabelling attributes), serta dapat meningkatkan pendapatan petani dan devisa. Menurut Widiarta et al. (2011), dari studi kasus yang dilakukan di Kecamatan Susukan, Kabupaten Semarang, Jawa Tengah diketahui bahwa pertanian organik memiliki banyak keunggulan dibandingkan dengan pertanian konvensional sehingga memiliki potensi keberlanjutan yang baik. Sebagai contoh, rasio B/C pertanian organik lebih tinggi dibandingkan dengan pertanian konvensional dengan nilai masing-masing 1.7 dan 0.9 . Hasil lain juga menunjukkan bahwa kompleksitas pertanian organik tidak berbeda dengan pertanian konvensional. Hal ini berarti bahwa pertanian organik, termasuk bawang merah organik sebenarnya mempunyai potensi yang tinggi untuk dikembangkan secara meluas di Indonesia.

Budidaya bawang merah selama ini dilakukan dengan sistem pertanian konvensional dengan penggunaan pupuk anorganik dan pestisida sintetik yang ternyata mempunyai rasio $\mathrm{B} / \mathrm{C}$ rendah akibat harga pupuk dan pestisida yang semakin mahal. Di samping itu penggunaan pupuk organik dan pestisida sintetik secara terus-menerus dalam jangka waktu yang panjang dapat menimbulkan dampak negatif seperti residu bahan kimia dalam produk pertanian, pencemaran lingkungan, dan munculnya organisme pengganggu tanaman (OPT) yang resisten. Pertanian organik menjadi solusi yang prospektif yang dapat mengatasi masalah tersebut dengan memanfaatkan potensi sumber daya alam yang ada.

Tanah-tanah di sentra produksi bawang merah seperti Brebes, Tegal, Subang, dan Bandung mempunyai permasalahan terutama dalam hal kandungan bahan organik dan kandungan N. Hasil penelitian Sumarni et al. (2012) menunjukkan bahwa tanah Aluvial di Brebes kandungan $\mathrm{C}$ organik dan $\mathrm{N}$-totalnya sangat rendah masing-masing $0.78 \%$ dan $0.06 \%$. Kandungan $\mathrm{C}$ organik dan N-total tanah inseptisol di Subang juga sangat rendah masing-masing $0.52 \%$ dan $0.06 \%$.

Masalah pemilihan jenis bahan organik menjadi penting karena masing-masing bahan organik mempunyai kelebihan dan kelamahan sendiri. Selain kandungan unsur hara yang tinggi dan lengkap, yang perlu dipertimbangkan adalah ketersediaan dalamjumlah yang tinggi dan kemudahan memperolehnya. Salah satu sumber bahan organik yang potensial adalah gulma yang keberadaannya bervariasi dan melimpah di Indonesia dan salah satunya adalah gulma siam. Pemanfaatan gulma sebagai bahan kompos mempunyai keuntungan ganda. Pertama, pemanfatan gulma dapat mengurangi kerugian akibat persaingan tanaman dengan gulma, dan kedua sekaligus mengubah gulma yang tadinya merugikan menjadi sesuatu yang bermanfaat.

Gulma siam (Chromolaena odorata L.) adalah gulma yang agresif karena kemampuannya untuk regenerasi dan mengkoloni suatu lahan, sehingga mendominasi vegetasi dengan menekan pertumbuhan gulma lain (Koutika dan Rainey, 2010). Gulma siam merupakan gulma utama pada pertanaman kelapa sawit, kelapa, kacang mete, karet, dan jeruk. Gulma siam dapat menghasilkan senyawa alelopati yang dapat menghambat pertumbuhan tanaman lainnya (Karim et al., 2017). Menurut Chakraborty et al., (2011), mula-mula gulma siam menyebar dan berkembang biak dengan biji, tetapi kemudian dapat memperbanyak diri secara vegetatif dengan cabang lateral, dan dapat tumbuh kembali setelah pembabatan atau pembakaran. Kemampuan pertumbuhan ini yang menyebabkan gulma siam berpotensi untuk dijadikan sebagai sumber bahan organik atau kompos. Penelitian ini bertujuan untuk mengetahui sebaran dan potensi gulma siam baik secara kuantitatif maupun kualitatifnya sebagai bahan pembuatan kompos untuk pengembangan bawang merah organik di Indonesia.

\section{BAHAN DAN METODE}

Penelitian ini merupakan penelitian deskriptif kuantitatif dengan metode survei yang dilakukan dari Maret sampai dengan April 2017 dan metode analisis laboratorium yang dilakukan pada 5 Juli 2017. Penentuan sampel menggunakan metode acak bertujuan (purposive random sampling) yaitu pemilihan sekelompok subyek yang berdasarkan ciri atau sifat tertentu yang mempunyai hubungan yang erat dengan ciri atau sifat populasi yang sudah diketahui sebelumnya (Alvi, 2016). Sampling dilakukan secara bertingkat menggunaan metode rancangan tersarang (nested design). Metode analisis jaringan digunakan untuk analisis kandungan unsur hara gulma siam.

Pengambilan data dilakukan di empat kabupaten di Propinsi Daerah Istimewa Yogyakarta (DIY) yaitu Bantul, Kulon Progo, Sleman dan Gunung Kidul. Dari setiap kabupaten dipilih tiga kecamatan kemudian dari kecamatan 
ditentukan dua desa. Pemilihan lokasi ini berdasarkan pertimbangan dugaan bahwa di lokasi tersebut terdapat habitat gulma siam. Dari 2 desa terpilih dicari 3 habitat gulma siam yaitu: 1) lahan-lahan kosong (bera), 2) lahan pertanian/di bawah tegakan, dan 3) pinggir jalan, yang mempresentasikan karakteristik masing- masing kondisi lahan. Dari setiap habitat ditentukan 3 kuadran berukuran masing- masing $1 \mathrm{~m} \mathrm{x} 1 \mathrm{~m}$ untuk pengamatan populasi dan bobot biomas gulma. Bobot biomas diketahui dengan menimbang seluruh bagian tajuk gulma tanpa mengikutkan akarnya. Teknik pengumpulan data yang digunakan dalam penelitian ini adalah observasi lapangan dengan melihat dan mendata secara langsung keberadaan gulma siam di masingmasing habitat. Analisis kandungan hara gulma siam $(\mathrm{N}, \mathrm{P}$, $\mathrm{K}$-total), $\mathrm{C}$ organik dan rasio $\mathrm{C} / \mathrm{N}$ menggunakan analisis jaringan dari seluruh bagian tajuk gulma.

Data dan informasi yang diperoleh dari hasil survei dideskripsikan dan dipaparkan untuk menjelaskan potensi gulma siam. Sidik ragam untuk rancangan tersarang (nested design) digunakan untuk membandingkan potensi gulma di antara lokasi/habitat gulma di empat kabupaten di Daerah Istimewa Yogyakarta (DIY).

Penanaman bawang merah dilakukan pada 16 Juni sampai dengan 8 September 2018 dengan perlakuan kontrol (tanpa pemupukan), kompos gulma siam dosis 10 dan 20 ton $\mathrm{ha}^{-1}$ serta pupuk anorganik NPK 16-16-16 dengan dosis $500 \mathrm{~kg} \mathrm{ha}^{-1}$ sebagai pembanding untuk mengetahui potensi gulma siam dalam budidaya bawang merah organik.

Kompos gulma siam dibuat dengan cara yang digunakan oleh Yuniwati et al. (2012). Daun dan batang gulma siam dicacah. EM4 dan gula pasir dilarutkan dengan air dengan konsentrasi akhir masing-masing $0.5 \%$ dan $0.8 \%$ kemudian didiamkan selama kurang lebih 3 jam. Sebanyak $2 \mathrm{~kg}$ cacahan gulma siam dihamparkan di atas lembaran plastik, disemprot merata dengan 1 L larutan EM4 dan diaduk-aduk agar bahan terbasahi secara merata. Campuran ini kemudian ditempatkan dalam wadah tertutup dan diletakkan di ruang gelap agar terjadi fermentasi. Setelah tiga hari campuran dibongkar kemudian dijemur beberapa hari untuk mengurangi kadar airnya. Setelah kering, kompos dihaluskan dan siap untuk diaplikasikan.

Penanaman bawang merah dilakukan di sentra penanaman bawang merah di daerah Kretek, Bantul, Yogyakarta dengan jarak tanam $20 \mathrm{~cm}$ x $20 \mathrm{~cm}$ pada petakpetak percobaan berukuran $11 \mathrm{~m}^{2}$ yang disusun dalam Rancangan Kelompok Lengkap Teracak dengan tiga blok sebagai ulangan. Pemberian pupuk kompos dilakukan sebelum penanaman bawang merah dengan mencampurkan secara merata dengan tanah lapisan atas. Pupuk anorganik diberikan dua kali yaitu sebelum tanam dan dua minggu setelah tanam masing-masing setengah dosis. Variabel yang diamati meliputi jumlah daun, tinggi tanaman, bobot segar dan bobot kering tanaman, bobot panen umbi dan jumlah umbi per tanaman, serta bobot panen umbi per ha. Data dianalisis dengan sidik ragam dan bila terjadi beda nyata dilanjutkan dengan uji DMRT $\alpha=5 \%$.

\section{HASIL DAN PEMBAHASAN}

\section{Kepadatan Populasi Gulma Siam}

Gulma siam dapat ditemui di semua lokasi di 4 kabupaten yang disurvei, baik di habitat tepi jalan, lahan kosong, maupun di bawah tegakan dengan kepadatan populasi yang berbeda-beda untuk setiap kabupaten (Tabel 1). Kepadatan populasi tertinggi ditemui di Kabupaten Kulon Progo, diikuti oleh Kabupaten Bantul, Gunung Kidul, dan Sleman dengan rata-rata kepadatan masing-masing 37.2, 29.3, 29.1, dan 23.8 gulma $\mathrm{m}^{-2}$. Kepadatan populasi untuk masing-masing kecamatan di setiap kabupaten juga bervariasi, tetapi kepadatan populasi untuk masing-masing desa di setiap kecamatan seragam. Hal ini menunjukkan bahwa gulma siam mempunyai sebaran yang merata di semua lokasi yang disurvei.

Gulma siam bersifat invasif dan mampu mengganggu keragaman vegetasi melalui pertumbuhannya yang cepat, menghasilkan biomas yang tinggi, dan kemampuannya menghasilkan senyawa alelopat (Karim et al., 2017). Hal inilah yang menyebabkan gulma siam mampu mendominasi vegetasi dan menekan pertumbuhan gulma atau tumbuhan lain, sehingga di habitat tersebut gulma siam tumbuh sebagai vegetasi tunggal.

\section{Bobot Biomas Gulma Siam}

Biomas gulma siam menunjukkan potensi kuantitatif gulma siam sebagai bahan pembuatan kompos. Data biomas segar gulma siam (Tabel 2) menunjukkan adanya beda nyata antar kabupaten dalam potensi biomas gulma siam. Biomas tertinggi diperoleh di Kabupaten Bantul sebesar $8.08 \mathrm{~kg}$ $\mathrm{m}^{-2}$, diikuti secara berturut-turut oleh Kabupaten Kulon Progo, Gunung Kidul, dan Sleman sebesar 7.27, 6.07 dan $3.44 \mathrm{~kg} \mathrm{~m}^{-2}$, atau sekitar 80, 70, 60, dan 30 ton ha-1. Secara kuantitatif gulma siam di empat kabupaten tersebut sangat potensial digunakan sebagai bahan pembuatan kompos untuk pengembangan bawang merah organik. Produksi biomas ini jauh lebih tinggi dibandingkan dengan produksi biomas gulma paitan (Tithonia diversifolia) sebesar 4 ton ha-1 (Reis et al., 2018) yang juga berpotensi digunakan sebagai bahan kompos. Produksi biomas gulma siam yang tinggi tersebut berkaitan dengan kemampuan pertumbuhannya yang sangat cepat dan mampu menghambat pertumbuhan spesies lain (Hamidi et al., 2014).

\section{Kandungan Hara Gulma Siam}

Analisis kandungan N, P, K total, C organik, dan rasio $\mathrm{C} / \mathrm{N}$ gulma siam dilakukan untuk mengetahui potensi kualitatif gulma siam sebagai bahan pembuatan kompos (Tabel 3). Kandungan N total tidak berbeda nyata untuk tiga kabupaten yaitu Kabupaten Kulon Progo. Sleman dan Bantul dan ketiganya lebih tinggi daripada Kabupaten Gunung 
Tabel 1. Kepadatan populasi gulma siam (individu $\mathrm{m}^{-2}$ ) untuk masing-masing lokasi dan habitat terpilih

\begin{tabular}{|c|c|c|c|c|c|c|}
\hline \multirow{2}{*}{ Kabupaten } & \multirow{2}{*}{ Kecamatan } & \multirow{2}{*}{ Desa } & \multicolumn{3}{|c|}{ Lokasi } & \multirow{2}{*}{ Rerata } \\
\hline & & & Tepi jalan & Lahan kosong & Bawah tegakan & \\
\hline \multirow[t]{10}{*}{ Kulon Progo } & Nanggulan & Donomulyo & 34.37 & 42.40 & 30.07 & $35.61 \mathrm{k}$ \\
\hline & & Banyuroto & 43.60 & 38.60 & 36.30 & $39.50 \mathrm{k}$ \\
\hline & & & & & Rerata Kecamatan & $37.56 \mathrm{pq}$ \\
\hline & Sentolo & Kaliagung & 34.90 & 35.40 & 37.00 & $35.77 \mathrm{k}$ \\
\hline & & Sentolo & 38.60 & 34.80 & 35.20 & $36.20 \mathrm{k}$ \\
\hline & & & & & Rerata Kecamatan & $35.98 \mathrm{pq}$ \\
\hline & Pengasih & Sendangsari & 37.60 & 36.00 & 36.20 & $36.60 \mathrm{k}$ \\
\hline & & Sidomulyo & 38.4 & 41.00 & 38.60 & $39.33 \mathrm{k}$ \\
\hline & & & & & Rerata Kecamatan & $37.97 \mathrm{p}$ \\
\hline & & & & & Rerata Kabupaten & $37.17 \mathrm{a}$ \\
\hline \multirow[t]{10}{*}{ Sleman } & Godean & Sidokarto & 24.01 & 25.80 & 24.47 & $24.76 \mathrm{k}$ \\
\hline & & Gancahan & 19.80 & 27.40 & 28.00 & $25.07 \mathrm{k}$ \\
\hline & & & & & Rerata Kecamatan & $24.91 \mathrm{r}$ \\
\hline & Gamping & Balecatur & 22.30 & 22.90 & 24.50 & $23.23 \mathrm{k}$ \\
\hline & & Ambarketawang & 24.34 & 18.60 & 21.60 & $21.51 \mathrm{k}$ \\
\hline & & & & & Rerata Kecamatan & $22.37 \mathrm{r}$ \\
\hline & Moyudan & Sumberagung & 29.60 & 20.40 & 26.00 & $25.33 \mathrm{k}$ \\
\hline & & Sumberarum & 16.87 & 27.80 & 23.60 & $22.76 \mathrm{k}$ \\
\hline & & & & & Rerata Kecamatan & $24.05 \mathrm{r}$ \\
\hline & & & & & Rerata Kabupaten & $23.78 \mathrm{c}$ \\
\hline \multirow[t]{10}{*}{ Bantul } & Kasian & Taman Tirto & 18.00 & 24.00 & 25.00 & $22.33 \mathrm{k}$ \\
\hline & & Bangun Jiwo & 18.00 & 34.00 & 29.00 & $27.00 \mathrm{k}$ \\
\hline & & & & & Rerata Kecamatan & $24.67 \mathrm{r}$ \\
\hline & Imogiri & Wukir sari & 33.00 & 27.00 & 29.00 & $29.67 \mathrm{k}$ \\
\hline & & Nawungan & 30.00 & 33.00 & 33.00 & $32.00 \mathrm{k}$ \\
\hline & & & & & Rerata Kecamatan & $30.83 q$ \\
\hline & Dlingo & Terong & 29.00 & 32.00 & 31.00 & $30.67 \mathrm{k}$ \\
\hline & & Temuwuh & 39.00 & 32.00 & 31.00 & $34.00 \mathrm{k}$ \\
\hline & & & & & Rerata Kecamatan & $32.33 q$ \\
\hline & & & & & Rerata Kabupaten & $29.28 \mathrm{ab}$ \\
\hline Gunung & Playen & Gading & 29.00 & 30.00 & 33.00 & $30.67 \mathrm{k}$ \\
\hline \multirow[t]{9}{*}{ Kidul } & & Pelembutan & 25.00 & 31.00 & 32.00 & $29.33 \mathrm{k}$ \\
\hline & & & & & Rerata Kecamatan & $30.00 \mathrm{qr}$ \\
\hline & Panggang & Legundi & 32.00 & 37.00 & 38.00 & $35.67 \mathrm{k}$ \\
\hline & & Girimulyo & 30.00 & 41.00 & 25.00 & $32.00 \mathrm{k}$ \\
\hline & & & & & Rerata Kecamatan & $33.83 \mathrm{pq}$ \\
\hline & Patuk & Patuk & 27.00 & 28.00 & 22.00 & $25.67 \mathrm{k}$ \\
\hline & & Beji & 20.00 & 19.00 & 24.00 & $21.00 \mathrm{k}$ \\
\hline & & & & & Rerata Kecamatan & $23.33 \mathrm{r}$ \\
\hline & & & & & Rerata Kabupaten & $29.06 b$ \\
\hline
\end{tabular}

Keterangan: Angka yang diikuti huruf yang sama pada kolom yang sama untuk setiap Desa, Kecamatan, dan Kabupaten tidak berbeda nyata berdasarkan DMRT pada $\alpha=5 \%$ 
Tabel 2. Biomas segar gulma siam $\left(\mathrm{kg} \mathrm{m}^{-2}\right)$ untuk masing-masing lokasi dan habitat gulma

\begin{tabular}{|c|c|c|c|c|c|c|}
\hline \multirow{2}{*}{ Kabupaten } & \multirow{2}{*}{ Kecamatan } & \multirow{2}{*}{ Desa } & \multicolumn{3}{|c|}{ Lokasi } & \multirow{2}{*}{ Rerata } \\
\hline & & & Tepi jalan & Lahan kosong & Bawah tegakan & \\
\hline \multirow[t]{10}{*}{ Kulon Progo } & Nanggulan & Donomulyo & 9.28 & 8.12 & 10.78 & $9.39 \mathrm{k}$ \\
\hline & & Banyuroto & 8.66 & 6.70 & 8.37 & $7.91 \mathrm{k}$ \\
\hline & & & & & Rerata Kecamatan & $8.65 p q$ \\
\hline & Sentolo & Kaliagung & 5.05 & 6.02 & 7.74 & $6.27 \mathrm{k}$ \\
\hline & & Sentolo & 5.80 & 6.85 & 6.74 & $6.46 \mathrm{k}$ \\
\hline & & & & & Rerata Kecamatan & $6.37 \mathrm{q}$ \\
\hline & Pengasih & Sendangsari & 8.26 & 6.90 & 6.26 & $7.14 \mathrm{k}$ \\
\hline & & Sidomulyo & 6.48 & 6.48 & 6.40 & $6.45 \mathrm{k}$ \\
\hline & & & & & Rerata Kecamatan & $6.80 \mathrm{q}$ \\
\hline & & & & & Rerata Kabupaten & $7.27 \mathrm{ab}$ \\
\hline \multirow[t]{10}{*}{ Sleman } & Godean & Sidokarto & 3.95 & 3.46 & 2.98 & $3.46 \mathrm{k}$ \\
\hline & & Gancahan & 3.20 & 3.24 & 3.26 & $3.23 \mathrm{k}$ \\
\hline & & & & & Rerata Kecamatan & $3.35 \mathrm{r}$ \\
\hline & Gamping & Balecatur & 3.11 & 2.89 & 3.73 & $3.24 \mathrm{k}$ \\
\hline & & Ambarketawang & 3.46 & 3.60 & 2.94 & $3.33 \mathrm{k}$ \\
\hline & & & & & Rerata Kecamatan & $3.29 \mathrm{r}$ \\
\hline & Moyudan & Sumberagung & 3.22 & 3.86 & 3.14 & $3.41 \mathrm{k}$ \\
\hline & & Sumberarum & 3.00 & 5.53 & 3.42 & $3.98 \mathrm{k}$ \\
\hline & & & & & Rerata Kecamatan & $3.70 \mathrm{r}$ \\
\hline & & & & & Rerata Kabupaten & $3.44 \mathrm{c}$ \\
\hline \multirow[t]{10}{*}{ Bantul } & Kasian & Taman Tirto & 10.90 & 5.30 & 5.40 & $7.20 \mathrm{k}$ \\
\hline & & Bangun Jiwo & 2.30 & 7.20 & 7.00 & $5.50 \mathrm{k}$ \\
\hline & & & & & Rerata Kecamatan & $6.35 \mathrm{qr}$ \\
\hline & Imogiri & Wukir sari & 9.20 & 7.90 & 7.30 & $8.13 \mathrm{k}$ \\
\hline & & Nawungan & 5.40 & 7.70 & 8.60 & $7.23 \mathrm{k}$ \\
\hline & & & & & Rerata Kecamatan & $7.68 \mathrm{pq}$ \\
\hline & Dlingo & Terong & 8.00 & 6.80 & 8.90 & $7.90 \mathrm{k}$ \\
\hline & & Temuwuh & 10.10 & 6.80 & 20.70 & $12.53 \mathrm{k}$ \\
\hline & & & & & Rerata Kecamatan & $10.22 p$ \\
\hline & & & & & Rerata Kabupaten & $8.08 \mathrm{ab}$ \\
\hline \multirow{10}{*}{$\begin{array}{l}\text { Gunung } \\
\text { Kidul }\end{array}$} & Playen & Gading & 4.90 & 6.60 & 7.40 & $6.30 \mathrm{k}$ \\
\hline & & Pelembutan & 6.40 & 6.60 & 6.50 & $6.50 \mathrm{k}$ \\
\hline & & & & & Rerata Kecamatan & $6.40 \mathrm{q}$ \\
\hline & Panggang & Legundi & 6.60 & 6.30 & 8.90 & $7.27 \mathrm{k}$ \\
\hline & & Girimulyo & 5.20 & 7.60 & 5.40 & $6.07 \mathrm{k}$ \\
\hline & & & & & Rerata Kecamatan & $6.67 \mathrm{q}$ \\
\hline & Patuk & Patuk & 5.90 & 6.20 & 4.30 & $5.47 \mathrm{k}$ \\
\hline & & Beji & 4.10 & 4.50 & 5.80 & $4.80 \mathrm{k}$ \\
\hline & & & & & Rerata Kecamatan & $5.13 \mathrm{qr}$ \\
\hline & & & & & Rerata Kabupaten & $6.07 \mathrm{~b}$ \\
\hline
\end{tabular}

Keterangan: Angka yang diikuti huruf yang sama pada kolom yang sama untuk setiap Desa, Kecamatan, dan Kabupaten tidak berbeda nyata berdasarkan DMRT pada $\alpha=5 \%$ 
Tabel 3. Kandungan C organik, N, P, K total dan C/N ratio gulma siam

\begin{tabular}{|c|c|c|c|c|c|c|c|}
\hline Kabupaten & Kecamatan & Desa & C Organik \% & N Total $\%$ & P Total $\%$ & K Total $\%$ & C/N Ratio \\
\hline \multirow[t]{10}{*}{ Kulon Progo } & \multirow[t]{3}{*}{ Nanggulan } & Donomulyo & $49.03 \mathrm{k}$ & $2.44 \mathrm{k}$ & $0.48 \mathrm{k}$ & $1.79 \mathrm{k}$ & $20.56 \mathrm{klm}$ \\
\hline & & Banyuroto & $51.50 \mathrm{k}$ & $2.44 \mathrm{k}$ & $0.42 \mathrm{k}$ & $1.70 \mathrm{k}$ & $21.12 \mathrm{klm}$ \\
\hline & & Rerata Kecamatan & $50.27 \mathrm{p}$ & $2.44 p$ & $0.45 p$ & $1.75 \mathrm{p}$ & $20.84 q$ \\
\hline & \multirow[t]{3}{*}{ Sentolo } & Kaliagung & $51.35 \mathrm{k}$ & $2.64 \mathrm{k}$ & $0.42 \mathrm{k}$ & $1.89 \mathrm{k}$ & $19.82 \mathrm{klm}$ \\
\hline & & Sentolo & $48.89 \mathrm{k}$ & $2.30 \mathrm{k}$ & $0.13 \mathrm{k}$ & $2.12 \mathrm{k}$ & $21.78 \mathrm{~m}$ \\
\hline & & Rerata Kecamatan & $50.12 p$ & $2.47 \mathrm{p}$ & $0.28 \mathrm{p}$ & $1.01 \mathrm{p}$ & $20.80 \mathrm{r}$ \\
\hline & \multirow[t]{4}{*}{ Pengasih } & Sendangsari & $51.73 \mathrm{k}$ & $2.41 \mathrm{k}$ & $0.42 \mathrm{k}$ & $1.93 \mathrm{k}$ & $22.00 \mathrm{kl}$ \\
\hline & & Sidomulyo & $52.46 \mathrm{k}$ & $2.33 \mathrm{k}$ & $0.25 \mathrm{k}$ & $1.75 \mathrm{k}$ & $22.81 \mathrm{k}$ \\
\hline & & Rerata Kecamatan & $52.10 \mathrm{p}$ & $2.37 \mathrm{p}$ & $0.34 p$ & $1.84 \mathrm{p}$ & $22.413 p$ \\
\hline & & Rerata Kabupaten & $50.83 b c$ & $2.43 \mathrm{a}$ & $0.36 \mathrm{a}$ & $1.53 \mathrm{~b}$ & $17.74 b c$ \\
\hline \multirow[t]{3}{*}{ Sleman } & \multirow[t]{3}{*}{ Godean } & Sidokarto & $50.92 \mathrm{k}$ & $2.97 \mathrm{k}$ & $0.42 \mathrm{k}$ & $2.38 \mathrm{k}$ & $17.38 \mathrm{klm}$ \\
\hline & & Gancahan & $51.19 \mathrm{k}$ & $2.49 \mathrm{k}$ & $0.45 \mathrm{k}$ & $2.45 \mathrm{k}$ & $20.83 \mathrm{klm}$ \\
\hline & & Rerata Kecamatan & $51.05 \mathrm{p}$ & $2.73 p$ & $0.43 p$ & $2.41 \mathrm{p}$ & $19.11 q$ \\
\hline \multirow[t]{3}{*}{ Gamping } & & Balecatur & $51.09 \mathrm{k}$ & $2.44 \mathrm{k}$ & $0.38 \mathrm{k}$ & $2.24 \mathrm{k}$ & $20.95 \mathrm{klm}$ \\
\hline & & Ambarketawang & $50.74 \mathrm{k}$ & $2.51 \mathrm{k}$ & $0.25 \mathrm{k}$ & $2.42 \mathrm{k}$ & $9.041 \mathrm{~m}$ \\
\hline & & Rerata Kecamatan & $50.91 p$ & $2.48 \mathrm{p}$ & $0.32 p$ & $2.33 p$ & $3.47 \mathrm{r}$ \\
\hline \multirow[t]{4}{*}{ Moyudan } & & Sumberagung & $51.96 \mathrm{k}$ & $2.48 \mathrm{k}$ & $0.32 \mathrm{k}$ & $2.36 \mathrm{k}$ & $21.15 \mathrm{klm}$ \\
\hline & & Sumberarum & $51.44 \mathrm{k}$ & $2.47 \mathrm{k}$ & $0.45 \mathrm{k}$ & $2.60 \mathrm{k}$ & $21.27 \mathrm{klm}$ \\
\hline & & Rerata Kecamatan & $51.70 \mathrm{p}$ & $2.48 p$ & $0.38 \mathrm{p}$ & $2.48 \mathrm{p}$ & $21.22 \mathrm{q}$ \\
\hline & & Rerata Kabupaten & $51.22 \mathrm{c}$ & $2.56 \mathrm{a}$ & $0.38 \mathrm{a}$ & $2.41 \mathrm{a}$ & $14.59 \mathrm{c}$ \\
\hline \multirow[t]{3}{*}{ Bantul } & \multirow[t]{3}{*}{ Kasian } & Tamantirto & $53.19 \mathrm{k}$ & $2.24 \mathrm{k}$ & $0.43 \mathrm{k}$ & $1.85 \mathrm{k}$ & $23.86 \mathrm{k}$ \\
\hline & & Bangunjiwo & $51.46 \mathrm{k}$ & $2.88 \mathrm{k}$ & $0.50 \mathrm{k}$ & $2.19 \mathrm{k}$ & $17.97 \mathrm{klm}$ \\
\hline & & Rerata Kecamatan & $52.32 \mathrm{p}$ & $2.56 \mathrm{p}$ & $0.46 \mathrm{p}$ & $2.02 \mathrm{p}$ & $20.91 \mathrm{q}$ \\
\hline \multirow[t]{3}{*}{ Imogiri } & & Wukirsari & $52.13 \mathrm{k}$ & $2.90 \mathrm{k}$ & $0.40 \mathrm{k}$ & $1.02 \mathrm{k}$ & $18.04 \mathrm{klm}$ \\
\hline & & Nawungan & $53.14 \mathrm{k}$ & $2.08 \mathrm{k}$ & $0.30 \mathrm{k}$ & $1.65 \mathrm{k}$ & $25.80 \mathrm{k}$ \\
\hline & & Rerata Kecamatan & $52.64 p$ & $2.49 p$ & $0.35 p$ & $1.34 \mathrm{p}$ & $21.92 \mathrm{q}$ \\
\hline \multirow[t]{4}{*}{ Dlingo } & & Terongan & $53.13 \mathrm{k}$ & $2.35 \mathrm{k}$ & $0.34 \mathrm{k}$ & $1.70 \mathrm{k}$ & $23.07 \mathrm{k}$ \\
\hline & & Temuwuh & $52.29 \mathrm{k}$ & $2.48 \mathrm{k}$ & $0.34 \mathrm{k}$ & $1.74 \mathrm{k}$ & $21.52 \mathrm{kl}$ \\
\hline & & Rerata Kecamatan & $52.71 \mathrm{p}$ & $2.42 p$ & $0.34 p$ & $1.72 p$ & $22.29 q$ \\
\hline & & Rerata Kabupaten & $52.56 \mathrm{ab}$ & $2.49 a$ & $0.38 \mathrm{a}$ & $1.69 \mathrm{~b}$ & $21.71 \mathrm{ab}$ \\
\hline Gunung & Playen & Gading & $53.57 \mathrm{k}$ & $1.88 \mathrm{k}$ & $0.36 \mathrm{k}$ & $1.45 \mathrm{k}$ & $28.62 \mathrm{k}$ \\
\hline \multirow[t]{9}{*}{ Kidul } & & Plembutan & $35.30 \mathrm{k}$ & $1.97 \mathrm{k}$ & $0.38 \mathrm{k}$ & $1.16 \mathrm{k}$ & $26.83 \mathrm{k}$ \\
\hline & & Rerata Kecamatan & $44.43 p$ & $1.93 p$ & $0.37 \mathrm{p}$ & $1.30 \mathrm{p}$ & $27.73 p$ \\
\hline & Pathuk & Pathuk & $53.21 \mathrm{k}$ & $2.08 \mathrm{k}$ & $0.33 \mathrm{k}$ & $1.53 \mathrm{k}$ & $25.72 \mathrm{k}$ \\
\hline & & Beji & $52.77 \mathrm{k}$ & $2.15 \mathrm{k}$ & $0.35 \mathrm{k}$ & $1.72 \mathrm{k}$ & $24.65 \mathrm{k}$ \\
\hline & & Rerata Kecamatan & $52.99 p$ & $2.12 p$ & $0.34 \mathrm{p}$ & $1.63 p$ & $25.18 p$ \\
\hline & Panggang & Giriwungu & $53.37 \mathrm{k}$ & $1.81 \mathrm{k}$ & $0.32 \mathrm{k}$ & $1.82 \mathrm{k}$ & $9.671 \mathrm{~m}$ \\
\hline & & Girimulyo & $53.03 \mathrm{k}$ & $1.88 \mathrm{k}$ & $0.34 \mathrm{k}$ & $1.79 \mathrm{k}$ & $28.66 \mathrm{k}$ \\
\hline & & Rerata Kecamatan & $53.20 \mathrm{p}$ & $1.84 p$ & $0.34 \mathrm{p}$ & $1.81 \mathrm{p}$ & $19.17 \mathrm{p}$ \\
\hline & & Rerata Kabupaten & $50.21 \mathrm{a}$ & $1.96 \mathrm{~b}$ & $0.35 \mathrm{a}$ & $1.58 \mathrm{~b}$ & $24.03 \mathrm{a}$ \\
\hline
\end{tabular}

Keterangan: Angka yang diikuti huruf yang sama pada kolom yang sama untuk setiap Desa, Kecamatan, dan Kabupaten tidak berbeda nyata berdasarkan DMRT pada $\alpha=5 \%$ 
Kidul yaitu sebesar 2.43, 2.56, 2.49, dan 1.96\%. Kandungan $\mathrm{N}$ total ini adalah kandungan $\mathrm{N}$ yang berasal dari seluruh bagian biomas yaitu batang dan daun gulma siam campuran (dewasa dan muda) yang tidak dipisahkan dengan harapan bahwa semua bagian biomas dapat dimanfaatkan sebagai bahan pembuatan pupuk kompos.

Kandungan $\mathrm{N}$ total gulma siam yang tinggi dari empat kabupaten juga menunjukkan potensinya sebagai bahan pembuatan kompos. Kandungan $\mathrm{N}$ tersebut lebih tinggi jika dibandingkan dengan kandungan $\mathrm{N}$ dari pupuk organik yang lain. Sebagai contoh hasil penelitian Irfan et al. (2017) menunjukkan bahwa kandungan $\mathrm{N}$ total dari kotoran sapi, kambing, dan ayam masing-masing adalah 0.4, 0.6, 1.0\% lebih rendah daripada kandungan $\mathrm{N}$ dalam gulma siam. Kandungan $\mathrm{N}$ total untuk masing-masing kecamatan dalam setiap kabupaten, dan masing-masing desa dalam setiap kecamatan tidak berbeda nyata berkisar antara 1.84\% di Kecamatan Panggang, Gunung Kidul dan 2.73\% di Kecamatan Godean, Sleman.

Berbeda dengan kandungan $\mathrm{N}$ total, kandungan $\mathrm{P}$ total untuk masing-masing kabupaten tidak berbeda nyata, berkisar antara $0.35-0.38 \%$, demikian juga untuk masingmasing kecamatan dan desa. Kandungan $\mathrm{K}$ total berbeda untuk masing-masing kabupaten dengan nilai tertinggi diperoleh di Kabupaten Sleman sebedar 2.41\%. dan terendah di Kabupaten Kulon Progo sebesar 1.53\% namun tidak berbeda nyata dengan Kabupaten Bantul dan Gunung Kidul. Kandungan $\mathrm{K}$ total tidak berbeda untuk masingmasing kecamatan di setiap kabupaten, dan masing-masing desa di setiap kecamatan yang disurvei.

Kandungan $\mathrm{P}$ dan $\mathrm{K}$ total tersebut juga menunjukkan secara kualitatif gulma siam potensial digunakan sebagai bahan pembuatan kompos. Dibandingkan dengan pupuk organik lain, kandungan kedua unsur tersebut relatif lebih tinggi. Sebagai contoh penelitian Ismayana et al. (2012) menunjukkan bahwa kandungan $\mathrm{P}$ dan $\mathrm{K}$ dalam blotong berturut-turut adalah 0.17 dan $0.034 \%$ jauh lebih rendah daripada kandungan $\mathrm{P}$ dan $\mathrm{K}$ dalam gulma siam.

Kecepatan dekomposisi bahan pembuatan kompos tergantung pada kualitas bahan organik terutama adalah nilai rasio $\mathrm{C} / \mathrm{N}$. Bahan organik lebih mudah termineralisasi apabila rasio $\mathrm{C} / \mathrm{N}$ nya di bawah nilai kritis yaitu 30 (Ismayana et al., 2012). Tabel 3 menunjukkan bahwa gulma siam merupakan bahan kompos yang baik karena mempunyai nilai rasio $\mathrm{C} / \mathrm{N}$ di bawah nilai kritis. Nilai rasio $\mathrm{C} / \mathrm{N}$ gulma siam bervariasi di setiap kabupaten tetapi semuanya di bawah nilai kritis yaitu berkisar antara 14.59 di Kabupaten Sleman dan tertinggi 24.03 di Kabupaten Gunung Kidul. Hal ini juga menunjukkan bahwa gulma siam sangat potensial digunakan sebagai bahan pembuatan kompos untuk pengembangan bawang merah organik.

\section{Pertumbuhan dan Hasil Bawang Merah}

Pertumbuhan (jumlah daun, tinggi tanaman, bobot segar dan bobot kering tanaman) dan hasil (bobot panen per tanaman, jumlah umbi, dan bobot panen per ha) disajikan dalam Tabel 4. Tabel 4 menunjukkan bahwa penggunaan pupuk kompos gulma siam pada dosis 10 ton ha ${ }^{-1}$ mampu memberikan jumlah daun dan tinggi tanaman yang lebih baik dibandingkan dengan pupuk anorganik NPK 16-1616 , tetapi tidak berbeda nyata pada variabel bobot segar dan bobot kering tanaman. Penggunaan pupuk organik gulma siam memberikan hasil yang tidak berbeda nyata dengan penggunaan pupuk anorganik NPK 16-16-116. Hal ini menunjukkan bahwa gulma siam sangat potensial digunakan untuk pengembangan budidaya organik bawang merah.

Hasil analisis tanah sebelum digunakan untuk penanaman bawang merah menunjukkan bahwa kandungan N-total temasuk kategori rendah yaitu $0.13 \%$, tetapi kandungan bahan organik, $\mathrm{P}$ dan $\mathrm{K}$ total termasuk kategori tinggi, masing-masing $10 \%$, 1042 ppm, dan 522 ppm. Hal ini berarti yang menjadi faktor pembatas produktivitas tanah tersebut adalah ketersediaan unsur hara N. Sementara itu hasil analisis kandungan unsur hara $\mathrm{N}$ dalam kompos gulma yang digunakan termasuk tinggi yaitu $2.45 \%$, sehingga mampu mencukupi kebutuhan $\mathrm{N}$ bagi tanaman.

Hasil yang sama didapatkan oleh Yuliatmi et al. (2015) yang melaporkan bahwa penggunaan kompos gulma siam meningkatkan pertumbuhan kedelai yang ditanam di tanah reklamasi bekas tambang batubara, dan Naik et al. (2016) yang mendapatkan bahwa penggunaan kompos gulma siam dapat meningkatkan pertumbuhan dan hasil jewawut (Eleusine coracana). Hal ini karena gulma siam mempunyai potensi pupuk dan meningkatkan bahan organik tanah pada tingkat yang cukup untuk memberi nutrisi pada tanaman

Tabel 4. Pertumbuhan dan hasil bawang merah pada penggunaan kompos gulma siam dibandingkan dengan kontrol dan penggunaan pupuk anorganik

\begin{tabular}{lccccccc}
\hline Perlakuan & $\begin{array}{c}\text { Jumlah } \\
\text { daun } \\
(7 \mathrm{mst})\end{array}$ & $\begin{array}{c}\text { Tinggi } \\
\text { tanaman } \\
(7 \mathrm{mst})\end{array}$ & $\begin{array}{c}\text { Bobot segar } \\
\text { tanaman }(\mathrm{g})\end{array}$ & $\begin{array}{c}\text { Bobot } \\
\text { kering } \\
\text { tanaman }(\mathrm{g})\end{array}$ & $\begin{array}{c}\text { Bobot } \\
\text { panen } \\
\text { umbi }(\mathrm{g})\end{array}$ & $\begin{array}{c}\text { Jumlah } \\
\text { umbi }\end{array}$ & $\begin{array}{c}\text { Bobot panen } \\
\text { umbi ha' } \\
\text { (ton) }\end{array}$ \\
\hline Kontrol (tanpa pemupukan) & $38.1 \mathrm{~b}$ & $51.57 \mathrm{a}$ & 143.44 & 13.15 & 84.69 & 10.6 & 18.92 \\
Kompos gulma siam 10 ton ha $^{-1}$ & $49.1 \mathrm{a}$ & $52.25 \mathrm{a}$ & 149.18 & 15.17 & 106.94 & 13.3 & 19.71 \\
Kompos gulma siam 20 ton ha $^{-1}$ & $48.4 \mathrm{~b}$ & $51.20 \mathrm{a}$ & 152.62 & 15.96 & 113.65 & 13.1 & 19.59 \\
Pupuk anorganik NPK 16-16-16 & $38.1 \mathrm{~b}$ & $43.09 \mathrm{~b}$ & 130.84 & 12.95 & 76.49 & 10.1 & 15.56 \\
\hline
\end{tabular}

Keterangan: Angka yang diikuti huruf yang sama pada kolom yang sama menunjukkan tidak berbeda nyata berdasarkan DMRT pada pada $\alpha=5 \%$ mst $=$ minggu setelah tanam 
(Ojeniyi et al., 2012).

\section{KESIMPULAN}

Gulma siam sangat potensial sebagai bahan pembuatan kompos untuk pengembangan bawang merah organik di Indonesia. Secara kuantitatif gulma siam mampu menghasilkan biomas yang sangat tinggi mencapai 80 ton biomas segar ha-1 pada kerapatan mencapai 24-37 individu $\mathrm{m}^{-2}$ dan tersebar di hampir seluruh lokasi di wilayah Daerah Istimewa Yogyakarta. Secara kualitatif gulma siam mengandung unsur hara yang tinggi yaitu masing- masing $2.56 \% \mathrm{~N}, 0.38 \% \mathrm{P}$, dan $2.41 \% \mathrm{~K}$ dengan rasio $\mathrm{C} / \mathrm{N}$ di bawah titik kritis sehingga mudah dan cepat termineralisasi. Penggunaan kompos gulma siam memberikan jumlah daun yang lebih tinggi pada 7 minggu setelah tanam dibandingkan dengan penggunaan pupuk inorganik dan kontrol, tetapi memberikan bobot umbi ha ${ }^{-1}$ yang tidak berbeda nyata yaitu masing-masing 19.71, 15.56 and 18.92 ton $\mathrm{ha}^{-1}$.

\section{DAFTAR PUSTAKA}

Alvi, M.H. 2016. A manual for selecting sampling techniques in research. University of Karachi, Iqra University.

Chakraborty, A.K., S. Rambhade, U.K. Patil. 2011. Chromolaena odorata (L.) : an overview. J. Phar. Res. 4:573-576.

Hamidi, F.W.A., A.M. Ismail, F.H.I. Zainuddin, M. Y. Hasan. 2014. Preliminary studi on allelopathic effect from Chromolaena odorata (siam weed) leaves extract towards Vigna radiata. Int. J. Eng. Res. Tech. 3:406-411.

Irfan, Rasdiansyah, M. Munadi. 2017. Kualitas bokasi dari kotoran berbagai jenis hewan. J. Tek. Industri Pert. Indonesia 9:23-27.

Ismayana, A., N.S. Indrasti, Suprihatin, A. Maddu, A. Fredy. 2012. Faktor rasio $\mathrm{C} / \mathrm{N}$ awal dan laju aerasi pada proses co-composting bagasse dan blotong. J. Tek. Ind. Pert. 22:173-179.

Karim, S.M.R., F. Zahan, L. Naher, R. Osama, M.A. Hakim. 2017. Inhibiting effects of siam weed (Chromolaena odorata (L.) King \& Robinson) on seed germination and seedling growth of four crops. Bangladesh J. Bot. 46:473-480.

Koutika, L.S., H.J. Rainey. 2010. Chromolaena odorata in different ecosystems: weed or fallow plant? Appl. Ecol. Environ. Res. 8:131-142.
Naik, K., A. H., R.T.V. Prasad, T. B, Naik. 2016. Influence of Chromolaena odorata compost on growth yield of finger millet. IOSR J. Agric. Vet. Sci. 9:20-24.

Ojeniyi, S.O., S.A. Odedina, T.M. Agbede. 2012. Soil productivity improving attributes of Mexican sunflower (Tithonia diversifolia) and siam weed (Chromolaena odorata). Emir. J. Food Agric. 24:243-247.

Paranata, A., A. T. Umam. 2015. Pengaruh harga bawang merah terhadap produksi bawang merah di Jawa Tengah. Jejak 8:36-44.

Reis, M.M., L. D.T. Santos, R.F. Pegoraro, M.V. Santos, F. Colen, W.G. Montes, R.R. Moura Jr., L.R. da Cruz, F.G. Oliveira. 2018. Productive and nutritional aspects of Tithonia diversifolia fertilized with biofertilizer and irrigated. J. Agric. Sci. 10:367-379.

Simatupang, S., T. Sipahutar, A.N. Sutanto. 2017. Kajian usahatani bawang merah dengan paket teknologi Good Agriculture Practices. J. Pengkajian Pengembangan Tek. Pert. 2:13-24.

Siagian, V.J. 2016. Outlook bawang merah. Dalam Nuryati, L., B. Warianto (Eds). Pusat Data dan Sistem Informasi Pertanian Kementerian Pertanian

Sumarni, N., R. Rosliani, R.S. Basuki, Y. Hilman. 2012. Respons tanaman bawang merah terhadap pemupukan fosfat pada beberapa tingkat kesuburan lahan (status P-tanah). J. Hort. 22:129-137.

Widiarta, A., S. Adiwibowo, Widodo. 2011. Analisis keberlanjutan praktik pertanian organik di kalangan petani. Sodality: Jurnal Transdisiplin Sosiologi, Komunikasi, dan Ekologi Manusia 5:71-89.

Yuliatmi, S., H. Ellya, A. Mursyid, Rodinah. 2015. Pengaruh bobot bahan organik daun kirinyu (Chromolaena odorata L.) di lahan reklamasi bekas batu bara terhadap pertumbuhan kedelai. Agrisains 1:78-84.

Yuniwati, M., F. Iskarima, A. Padulemba. 2012. Optimasi kondisi proses pembuatan kompos dari sampah organik dengan cara fermentasi menggunakan EM4. J. Teknologi 5:172-181. 